\title{
乳児期の栄養摂取法を異にする乳幼児および 学童の頭部形態の発育
}

一一特に人工栄養児の短頭化傾向について——

島田彰 夫*

\section{Different Methods of Infant Feeding and the Growth of Head in Infants and Children: With the Special Reference to Brachycephalization of Artificially Fed Children}

\section{Akio SHIMADA*}

Cross sectional investigation on the growth of head were examined in Sendai in 1969. Examinees were divided into three groups by the different methods of infant feeding, such as 1) breast feeding. 2) mixed feeding of breast and artificial, and 3) artificial feeding. The total number of the examinees were 2,796. Their age groups were four month-, three year-, five year-, ten year- and twelve year-ages of both sexes.

These data were analyzed and discussed by the epidemiological procedures. The results are as follows:

1) Four months artificially fed male infants showed significantly smaller value than breast fed male infants $(\mathrm{p}<0.05)$ in height, weight and girth of chest. No significant differences were observed in other groups on these items.

2) Four months breast fed infants showed larger value in girth of head than artificially fed infants in male $(p<0.0001)$. Girth of head of artificially fed female children showed rather smaller value than breast fed children, and there were significant differences in three years and five years children $(\mathrm{p}<0.05)$.

3) Head length of artificially fed children showed smaller value than breast fed children in every age groups of both sexes, and the significant differences were shown in the groups of four months and ten years of male $(p<0.05)$. Head width of artificially fed children showed rather wider values than breast fed children. However, significant differences were observed only in twelve year-age of male $(p<0.05)$. Mixed fed children showed intermediate value between these two groups in the items of head length and width.

4) Significant correlation was not observed between the methods of infant feeding and the results of intelligence test.

*.秋田大学医学部衛生学教室（主任：加美山茂利教授）

* Dept. of Hygiene, Akita University School of Medicine. (Director: Prof. Sigetosi Kamiyama), 
5) It is supposed that the morphological development of the head is influenced by the methods of infant feeding during the earliest stage, within four months, of the development of infant, and it would be brought to their adult age. It is also supposed that the nutritional intake, such as artificial feeding is one of the factors that increase the speed of brachycephalization.

はじめに

頭部形態の歷史的変遷については，これまでに 多くの研究があるが，特に鈴木 ${ }^{122}$ は短頭化現象と してこれをまとめている. このような現象は，わ が国に和いてばかりでなく，世界的に認められて いるにもかかわらず，その原因については，栄養 的な要因によるとするもの，文化的な要因による とするもの，物理的な要因によるとするものなど 諸説があって必ずしも一致しない. 同時代にあっ ても，附田 ${ }^{3)}$ は国内各地域間の頭型の差を，また 宮下4)5) は都市と農村, 並びに農村と漁村の間の頭 型の差を指摘している.

著者はこれらの事例を検討した結果，明治維新 後のわが国に和ける急激な短頭化に注目し，これ が明治維新後の栄養摂取の量的並びに質的な変化
によるものではないかと考えるに至ったので，同 一時代，同一地域に居住し，栄養摂取法の異なる 集団として，乳韭期の栄養に注目し，性別，年令 層別ならびに乳児期の栄養摄取法によって，母乳 栄養, 混合栄養, 人工栄養の 3 群にわけて, 頭部 形態の発育を中心とした比較を行ない，短頭化の 原因究明の一助となる 知見を得たのでここに報告 する。

\section{対象ならびに方法}

1. 対象者の概要

（1）性，年令層および栄養摂取法による群別 (表 1)

調查測定は仙台市南保健所管内に居住する 4 ケ 月児， 3 才児， 5 才児，10才児，12才児を対象に 行なわれた。同保健所管内は，仙台市の南部，東

表 1 栄養摄取群別調查対象者数ならびにその割合

\begin{tabular}{|c|c|c|c|c|c|c|c|c|}
\hline \multirow{2}{*}{$\begin{array}{l}\text { 性 } \\
\text { 別 }\end{array}$} & \multirow{2}{*}{ 年 令層 } & \multicolumn{2}{|c|}{ 母 乳 栄 養 群 } & \multicolumn{2}{|c|}{ 混 合 栄 荃 群 } & \multicolumn{2}{|c|}{ 人工栄 養群 } & \multirow{2}{*}{ 計 } \\
\hline & & 人 & $\%$ & 人 & $\%$ & 人 & $\%$ & \\
\hline \multirow{3}{*}{ 男 } & 4 ケ月児 & 118 & 24. 2 & 174 & 35.7 & 195 & 40.1 & 487 \\
\hline & 3 才児 & 44 & 16.6 & 59 & 22.3 & 162 & 61.1 & 265 \\
\hline & 5 才児 & 33 & 30.8 & 39 & 36.5 & 35 & 32.7 & 107 \\
\hline \multirow{3}{*}{ 児 } & 10 才児 & 108 & 33.3 & 112 & 34.6 & 104 & 32.1 & 324 \\
\hline & 12 才児 & 131 & 45.0 & 86 & 29.6 & 74 & 25.4 & 291 \\
\hline & 小 計 & 434 & & 470 & & 570 & & 1,474 \\
\hline \multirow{3}{*}{ 女 } & 4 ケ月児 & 114 & 25.7 & 176 & 39.7 & 153 & 35.6 & 443 \\
\hline & 3 才児 & 53 & 24.9 & 56 & 26.3 & 104 & 48.8 & 213 \\
\hline & 5 才児 & 33 & 26.8 & 46 & 37.4 & 44 & 35.8 & 123 \\
\hline \multirow{3}{*}{ 児 } & 10 才児 & 113 & 43.6 & 82 & 31.7 & 64 & 24.7 & 259 \\
\hline & 12 才児 & 149 & 52.5 & 83 & 29.2 & 52 & 18.3 & 284 \\
\hline & 小 計 & 462 & & 443 & & 417 & & 1,322 \\
\hline \multicolumn{2}{|c|}{ 合 } & 896 & & 913 & & 987 & & 2,796 \\
\hline
\end{tabular}


部に広がる住宅地，商業地を中心に，一部に近郊 数業地域を含み，人口約20万を推している.

同保健所に拈ける乳児検䛦の機会に4 ケ月児を 3 才児検診の機会に 3 才児について調查測定を行

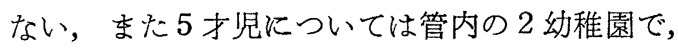
10才児ならびに12才児については 3 小学校に打い て，計測ならびに面接，アンケートによる乳児 期，とくに出生後4ケ月までの栄養掑取状況につ いて調査を実施した。混合栄養については，その 混合割合はさまざをであるが，1日に 1 回以上， 人工栄養，もしくは母乳を与えたものを全て混合 栄養として扱った，以下，栄養掑取法による群別
を母乳群，混合群，人工群と略称する.

栄養摂取法別の対象者の性別ならびに年令層 別構成は，表 1 に示した通りであり，総数济男児 1,474名，女児 1,322名，合計 2,796 名である.

これら被検者の出生時期は，4 ケ月児では 1969 年1月より 5 月まで，3才児では1965年11月より 1966年 5 月まで， 5 才児では 1964年 4 月より 1965 年 3 月まで, 10才児では 1959年 4 月より1960年 3 月まで，また12才児では，1957年 4 月より1958年 3 月までの出生者である.

（2）出生時の父母の年令（表 2, 表 3)

対象者の出生時に和ける父および母の平均年令

表 2 出生時の父の年令

\begin{tabular}{|c|c|c|c|c|c|c|c|c|c|c|c|c|c|}
\hline \multirow{2}{*}{$\begin{array}{l}\text { 性 } \\
\text { 別 }\end{array}$} & \multirow{2}{*}{ 区 分 } & \multicolumn{4}{|c|}{ 母 乳 栄 養 群 } & \multicolumn{4}{|c|}{ 混 合 栄 養 群 } & \multicolumn{4}{|c|}{ 人工栄 養 群 } \\
\hline & & $\mathrm{n}$ & M & S. E. & S. D. & $\mathrm{n}$ & $\mathbf{M}$ & S. E. & S. D. & $\mathrm{n}$ & $\mathbf{M}$ & S. E. & S. D. \\
\hline \multirow{3}{*}{ 男 } & 4 ケ月児 & 118 & 30.73 & 0.38 & 4. 15 & 165 & 30.26 & 0.32 & 4.17 & 187 & 30.36 & 0.28 & 3.86 \\
\hline & 3 才児 & 27 & 30.19 & 0.60 & 3.09 & 34 & 31.06 & 0.89 & 5.17 & 95 & 29.86 & 0.36 & 3.50 \\
\hline & 5 才児 & 26 & 29.31 & 0.67 & 3.41 & 37 & 31.70 & 0.66 & 4.01 & 30 & 31.40 & 0.62 & 3. 40 \\
\hline \multirow{2}{*}{ 児 } & 10 才児 & 105 & 31.61 & 0.41 & 4. 24 & 103 & 31.68 & 0.38 & 3. 88 & 99 & 31.32 & 0.44 & 4. 39 \\
\hline & 12 才児 & 122 & 31.16 & 0.36 & 3.95 & 76 & 31.58 & 0.48 & 4.22 & 59 & 31.24 & 0.57 & 4. 34 \\
\hline \multirow{3}{*}{ 女 } & 4 ケ月児 & 106 & 30.66 & 0.35 & 3. 61 & 166 & 30.93 & 0.32 & 4.08 & 131 & 30.44 & 0.35 & 4. 02 \\
\hline & 3 才児 & 51 & 30.14 & 0.53 & 3.76 & 42 & 30.19 & 0.55 & 3.57 & 56 & 30.64 & 0.61 & 4. 54 \\
\hline & 5 才児 & 24 & 29.17 & 0.73 & 3.56 & 39 & 30.23 & 0.56 & 3.50 & 35 & 30.43 & 0.56 & 3. 30 \\
\hline \multirow{2}{*}{ 児 } & 10 才児 & 107 & 31.30 & 0.45 & 4. 70 & 73 & 32.01 & 0.49 & 4.23 & 55 & 31.80 & 0.63 & 4. 68 \\
\hline & 12 才児 & 141 & 31.78 & 0.38 & 4. 57 & 73 & 31.52 & 0.48 & 4.08 & 46 & 31.87 & 0.53 & 3.60 \\
\hline
\end{tabular}

表 3 出生時の母の年令

\begin{tabular}{|c|c|c|c|c|c|c|c|c|c|c|c|c|c|}
\hline \multirow{2}{*}{$\begin{array}{l}\text { 性 } \\
\text { 別 }\end{array}$} & \multirow{2}{*}{ 年 } & \multicolumn{4}{|c|}{ 母 乳 栄 養 群 } & \multicolumn{4}{|c|}{ 混 合 栄 養 群 } & \multicolumn{4}{|c|}{ 人工 栄 養 群 } \\
\hline & & $\mathrm{n}$ & $\mathbf{M}$ & S. E. & S.D. & $\mathrm{n}$ & $\mathbf{M}$ & S.E. & S.D. & $\mathrm{n}$ & $\mathbf{M}$ & S.E. & S. D. \\
\hline \multirow{3}{*}{ 男 } & 4 ケ月児 & 119 & 27.37 & 0.3 & & 171 & 26.86 & 0. & & 192 & 27.36 & 30 & \\
\hline & 3 才児 & 27 & 26.41 & 0.58 & 3. 02 & 34 & 27.94 & 0.67 & & 95 & 26. 83 & 0.34 & $3.2 i$ \\
\hline & 5 才児 & 26 & 27.23 & 0.85 & 4. 34 & 37 & 28.30 & 0.53 & 3.20 & 30 & 28.07 & 0.78 & 4. 28 \\
\hline \multirow{2}{*}{ 児 } & 10 才児 & 105 & 27 & & 4.00 & 103 & 27.52 & & & 99 & 28. & 40 & 3. 98 \\
\hline & 12 才児 & 120 & 27.33 & 0.34 & 3. 67 & 76 & 27.47 & 0.43 & 3. 78 & 59 & 28.76 & 0.47 & 3.61 \\
\hline \multirow{3}{*}{ 女 } & 4 ケ月児 & 106 & & 0.07 & & 166 & 21.01 & 0.25 & & 131 & 27.27 & & \\
\hline & 3 才児 & 51 & 26.33 & 0.51 & 3.64 & 42 & 26.33 & 0.54 & 3.51 & 56 & 27.25 & 0.50 & 3.76 \\
\hline & 5 才児 & 24 & 26.92 & 0.82 & 4.0 & 39 & 27.05 & 0.56 & 3. 49 & 35 & 27.29 & 0.49 & 2. 91 \\
\hline \multirow[t]{2}{*}{ 児 } & 10 才児 & 107 & 27. 21 & 0.34 & & 73 & 27.77 & 0.48 & & 55 & 28.38 & 0.59 & 4. 38 \\
\hline & 12 才児 & 141 & 27.68 & 0.33 & 3.88 & 73 & 27.66 & 0.39 & 3.33 & 46 & 27. 91 & 0.51 & 3. 43 \\
\hline
\end{tabular}


は，表 2 ，表 3 に示すごとくであり，父母ともに 近年になるほど，やや若年化している傾向はみら れるが，5才男児の父で母乳群が人工群および混 合群に比し有意に若いこと（ $\mathrm{p}<0.05 ）$ ，また12才 男児の母で人工群が母乳群和よび混合群に比し有 意に高年であること（p<0.05）をのぞいては，各 年令層の父母ともに，群間に有意の差はみられな い.

\section{2. 調査時期ならびに方法}

4 ケ月児ならびに 3 才児については, 1969 年 5 月から 9 月にかけて，5才児，10才児ならびに 12 才児については，1969年10月に計測を実施した。 すなわち，調査時点に和ける対象者の年令は，4 ケ月児では，出生日から 4 ケ月 \pm 2 日， 3 才児に ついては，3才 6 ケ月土4日であり，5才児，10 才児，12才児については，それぞれ，平均で 5 才， 10才，12才であった.

身体計測に当っては，4 ケ月児については乳児 用の身長計ならびに体重計を用い臥位で，3才児 以上については一般用の身長計，体重計を用いて 立位で行なった。胸囲は各年令層とも布製巻尺に よって計測した.

頭部計測に当っては，頭囲は布製巻尺により， 頭長ならびに頭幅については，マルチン式測径器 を用いたが，乳児についても卧位とせず，立位で
計測した.

これらの計測值から乳幼児についてはカウプ指 数, 学童についてはローレル指数を, また, 頭部 については頭長幅指数を算出した.

\section{成䋡}

\section{1. 栄養摂取法別割合（表 1)}

調査対象者を性別，年令層別に乳児期の栄養掑 取法の出現率をみると，表 1 に示したよ5に，5 才児を除き, 各年令層共, 男児は女児に比して人 工栄養児が多く，母乳栄養児が少ないが，混合栄 養には男女のちがいはみられない。人工栄養児の 割合は，1957年 4 月から 1958年 3 月にかけて生ま れた12才児では，男児 $25.4 \%$ ，女児18.3\%である が，1965年11月から 1966年 3 月にかけて生まれた 3 才児では，男児 $61.1 \%$ ，女児 $48.8 \%$ と，その間 に 2.5 倍に增加したのに対し，母乳栄養児は男児 の12才で $45 \% ， 3$ 才では 16\%，女児では12才で $52 \% ， 3$ 才で $25 \%$ となり，それぞれ执よそ3 分の 1 扰よ゙ 2 分の 1 に激減している. この間，混合 栄養児については，大きな変化は認められなかっ た. しかし，1969年1月から5 月にかけて生まれ た 4 ケ月児については，母乳に対する認識が改め られるにつれて, 人工栄養児の激減と同時に, 母 乳栄養児の若干の増加, ならびに混合栄養児の急 増が認められ, 混合栄養を含む母乳の利用率は全

表 4 出生時体重

(g.)

\begin{tabular}{|c|c|c|c|c|c|c|c|c|c|c|c|c|c|}
\hline \multirow{2}{*}{$\begin{array}{l}\text { 性 } \\
\text { 別 }\end{array}$} & \multirow{2}{*}{ 区 分 } & \multicolumn{4}{|c|}{ 母 乳 栄 養 群 } & \multicolumn{4}{|c|}{ 混 合栄 養 群 } & \multicolumn{4}{|c|}{ 人工栄養 群 } \\
\hline & & $\mathrm{n}$ & M & S. E. & S. D. & $\mathrm{n}$ & $\mathbf{M}$ & S.'E. & S.D. & $\mathrm{n}$ & M & $S \cdot E$. & S. D. \\
\hline \multirow{3}{*}{ 男 } & 4 ケ月児 & 111 & 3333 & 40 & 429 & 166 & 3385 & 37 & 182 & 190 & 3203 & 37 & 515 \\
\hline & 3 才児 & 42 & 3261 & 56 & 364 & 49 & 3225 & 52 & 367 & 135 & 3274 & 31 & 366 \\
\hline & 5 才児 & 29 & 3215 & 68 & 368 & 35 & 3201 & 57 & 342 & 33 & 3171 & 59 & 340 \\
\hline \multirow{2}{*}{ 児 } & 10 才児 & 95 & 3220 & 43 & 422 & 89 & 3274 & 41 & 386 & 93 & 3142 & 35 & 343 \\
\hline & 12 才児 & 110 & 3203 & 37 & 389 & 77 & 3178 & 38 & 339 & 60 & 3215 & 50 & 394 \\
\hline \multirow{3}{*}{ 女 } & 4 ケ月児 & 96 & 3133 & 30 & 296 & 156 & 3230 & 32 & 405 & 137 & 3111 & 29 & 341 \\
\hline & 3 才児 & 41 & 3235 & 47 & 305 & 39 & 3278 & 50 & 315 & 78 & 3178 & 39 & 351 \\
\hline & 5 才児 & 31 & 3079 & 53 & 295 & 46 & 3032 & 43 & 296 & 41 & 3137 & 52 & 334 \\
\hline \multirow{2}{*}{ 児 } & 10 才児 & 105 & 3144 & 38 & 396 & 77 & 3114 & 43 & 378 & 58 & 3134 & 43 & 333 \\
\hline & 12 才児 & 124 & 3169 & 28 & 320 & 75 & 3140 & 36 & 319 & 44 & 3100 & 46 & 307 \\
\hline
\end{tabular}


体の約 3 分の 2 に達した.

\section{2. 出生時体重 (表 4)}

各栄養摂取群毎に, 出生時体重をみると表 4 の よ5に，男児では 4 ケ月児の母乳群が， $3,333 \pm$ $40 \mathrm{~g}$ と人工群の $3,203 \pm 37 \mathrm{~g}$ より有意に大きく $(\mathrm{p}$ $<0.05)$, 混合群も $3,385 \pm 37 \mathrm{~g}$ と人工群より大き かった $(\mathrm{p}<0.001)$ が，他には，10才児の混合群が $3,274 \pm 41 \mathrm{~g}$ と人工群の $3,142 \pm 35$ より大きかった （p０.05）だけであった，女児では 4 ケ月児で混 合群が $3,230 \pm 32 \mathrm{~g}$ と最も大きく，母乳群の 3,133 $\pm 30 \mathrm{~g}$ に対しては $\mathrm{p}<0.05$ ，人工群の $3,111 \pm 29 \mathrm{~g}$
に対しては $\mathrm{p}<0.01$ で有意の差が認められた. し かし，これら以外の各年令層では，男女とも有意 の差が認められず，また，一定の傾向も認められ なかった。

\section{3. 身体計測値}

(1) 身 長 (表 5 )

表 5 に示す通り，4 ケ月男児の人工群では 63.80 $\pm 0.17 \mathrm{~cm}$ と, 母乳群の $64.39 \pm 0.20 \mathrm{~cm}$ に比して 危険率 $5 \%$ 以下で，また混合群の $63.16 \pm 0.15 \mathrm{~cm}$ に比して危険率 $1 \%$ 以下で有意に小さく，4 ケ月 女児では, 混合群が $63.16 \pm 0.16 \mathrm{~cm}$ と母乳群の

表 5 身長

(cm)

\begin{tabular}{|c|c|c|c|c|c|c|c|c|c|c|c|c|c|}
\hline \multirow{2}{*}{$\begin{array}{l}\text { 性 } \\
\text { 別 }\end{array}$} & \multirow{2}{*}{ 年 令 } & \multicolumn{4}{|c|}{ 母 乳 栄 養 群 } & \multicolumn{4}{|c|}{ 混 合 栄 養 群 } & \multicolumn{4}{|c|}{ 人工栄 養 群 } \\
\hline & & $\mathrm{n}$ & M & S. E. & S. D. & $\mathrm{n}$ & $\mathbf{M}$ & S. E. & S. D. & $\mathrm{n}$ & $\mathbf{M}$ & S. E. & S. D. \\
\hline \multirow{3}{*}{ 男 } & 4 ケ月児 & 121 & 64.39 & 0.20 & 2.22 & 176 & 64.41 & 0.15 & & 195 & 63.80 & .17 & 2.40 \\
\hline & 3 才児 & 44 & 97.20 & 0.53 & 3.51 & 59 & 96.81 & 0.41 & 3.16 & 161 & 97.78 & 0.26 & 3. 31 \\
\hline & 5 才児 & 31 & 114.74 & 0.93 & 5.20 & 37 & 113.16 & 0.75 & 4.57 & 32 & 114.75 & 0.78 & 4. 44 \\
\hline \multirow{2}{*}{ 児 } & 10 才児 & 106 & 132.75 & 0.48 & 4. 94 & 110 & 132.07 & 0.52 & 5.46 & 104 & 131.42 & 0.51 & 5.23 \\
\hline & 12 才児 & 130 & 145.05 & 0.60 & 6.83 & 84 & 145.14 & 0.72 & 6.57 & 72 & 145.72 & 0.79 & 6.70 \\
\hline \multirow{3}{*}{ 女 } & 4 ケ月児 & 115 & 62.29 & 0.20 & 2.09 & 181 & 63.16 & 0.16 & & 156 & 62.47 & 0.10 & 2.23 \\
\hline & 3 才児 & 53 & 96.27 & 0.40 & 2.90 & 56 & 96.57 & 0.38 & 2.85 & 104 & 96.65 & 0.36 & 3.70 \\
\hline & 5 才児 & 33 & 111.30 & 0.71 & 4.09 & 46 & 113.35 & 0.82 & 5.54 & 39 & 112.23 & 0.73 & 4. 54 \\
\hline \multirow{2}{*}{ 児 } & 10 才児 & 112 & 131.27 & 0.59 & 6.29 & 79 & 131.99 & 0.74 & 6.55 & 63 & 130.43 & 0.91 & 7.23 \\
\hline & 12 才児 & 148 & 147.53 & 0.52 & 6.28 & 82 & 146.63 & 0.73 & 6.62 & 51 & 146.14 & 0.98 & 7.03 \\
\hline
\end{tabular}

表 6 体

重

（4 ケ月児 $\mathrm{g}, 3$ 才児以上 $\mathrm{kg}$ )

\begin{tabular}{|c|c|c|c|c|c|c|c|c|c|c|c|c|c|}
\hline \multirow{2}{*}{$\begin{array}{l}\text { 性 } \\
\text { 別 }\end{array}$} & \multirow{2}{*}{ 年 令 } & \multicolumn{4}{|c|}{ 母 乳 栄 養 群 } & \multicolumn{4}{|c|}{ 混 合 栄 養 群 } & \multicolumn{4}{|c|}{ 人工栄 養 群 } \\
\hline & & $\mathrm{n}$ & M & S. E. & S. D. & $\mathrm{n}$ & M & S. E. & S. D. & $\mathrm{n}$ & $\mathbf{M}$ & S. E. & S. D. \\
\hline \multirow{3}{*}{ 男 } & 4 ケ月児 & 121 & 7126 & 60 & 660 & 177 & 7133 & 49 & 651 & 191 & 6949 & 55 & 762 \\
\hline & 3 才児 & 44 & 14.75 & 0.20 & 1.33 & 58 & 14.69 & 0.19 & 1. 43 & 162 & 14.95 & 0.12 & 1.55 \\
\hline & 5 才児 & 31 & 19.50 & 0.45 & 2. 51 & 37 & 18.99 & 0.33 & 2. 10 & 32 & 19.63 & 0.35 & 1.96 \\
\hline \multirow{2}{*}{ 児 } & 10 才児 & 106 & 28.75 & 0.34 & 3.55 & 110 & 28.76 & 0.39 & 4.06 & 104 & 28.87 & 0.59 & 6.01 \\
\hline & 12 才児 & 130 & 37.42 & 0.62 & 7. 11 & 84 & 37.12 & 0.68 & 6.21 & 72 & 37.75 & 0.74 & 6.25 \\
\hline \multirow{3}{*}{ 女 } & 4 ケ月児 & 115 & 6548 & 71 & 761 & 181 & 6723 & 51 & 689 & 156 & 6512 & 49 & 615 \\
\hline & 3 才児 & 53 & 14.42 & 0.19 & 1.40 & 56 & 14.73 & 0.20 & 1.51 & 104 & 14. 42 & 0.16 & 1.65 \\
\hline & 5 才児 & 33 & 18.68 & 0.35 & 2.04 & 46 & 19. 22 & 0.44 & 2. 97 & 39 & 18.99 & 0.41 & 2.59 \\
\hline \multirow{2}{*}{ 児 } & . 10 才览 & 112 & 28.20 & 0.49 & 5.19 & 79 & 28. 72 & 0.60 & 5. 30 & 63 & 27.25 & 0.56 & 4. 46 \\
\hline & 12 才児 & 148 & 40.04 & 0.58 & 7.09 & 82 & 39.22 & 0.75 & 6.75 & 51 & $38: 41$ & 1.01 & 7.19 \\
\hline
\end{tabular}


$62.29 \pm 0.20 \mathrm{~cm}$ に比して危険率 $0.1 \%$ 以下で，ま た，人工群の $62.47 \pm 0.18 \mathrm{~cm}$ に比して危険率 1 \%以下で有意に大きかった注か，各年令層，男女 とも栄養掑取法のちがいによる差は認められず, また，一定の傾向も認められなかった。

男児は10才児までは，女児より各群とも平均值が 大であるが，12才児では，この関係は逆転し，女 児の平均值が男児のそれを上回り，男児が $145 \mathrm{~cm}$ 程度であるのに対し，女児は 146〜 $147 \mathrm{~cm}$ となっ た。

\section{（2）体 重（表6 )}

体重についても，表 6 に示したように身長と同 様な傾向がみられた４ヶ月男児の人工群は 6,949 $\pm 55 \mathrm{~g}$ で，母乳群の $7,126 \pm 60 \mathrm{~g}$ ，および混合群の $7,133 \pm 49 \mathrm{~g}$ に比し危険率 $5 \%$ 以下で有意に小さ

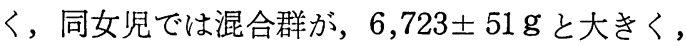
母乳群の $6,548 \pm 71 \mathrm{~g}$ との間に危険率 $5 \%$ 以下，

人工群の $6,512 \pm 49 \mathrm{~g}$ との間では危険率 $1 \%$ 以下 で有意の差が認められた。 しかし，3才児以上で は，各群間に男女とも有意の差はなく，また一定 の傾向も認められなかった。

4 ケ月児では，男児は女児に比して大であった が，3才児，5才児，10才児では殆んどちがわず， 12才児では女児の方が大であった。

（3）胸 囲（表 7 ）

胸囲の計測值も身長，体重と同様の傾向がみら
れ，4 ケ月男児の人工群が $43.39 \pm 0.15 \mathrm{~cm}$ と，母 乳群の $43.90 \pm 0.20 \mathrm{~cm}$ に比して有意に小さかった だけで，他には有意の差は認められなかった。特 に男児では， 3 才以上の母乳群と人工群との間に 全く差は認められなかった。 しかし，女览では10 才児，12才児で人工群が やや小さい傾向が認めら れたが，有意差には達しなかった。

（4）カウプ指数またはローレル指数（表 8）

表のよ5に，身長，体重の計測值から，4 ケ月 児，3才児，5才児についてはカウプ指数を，ま た，10才児，12才児についてはローレル指数を算 出した.

4 ケ月児では男女とも母乳群が大きく, 混合群, 人工群の順であったが，各群間に有意の差は認め られなかった３才児以上の男児には，特定の傾 向はなく，また有意の差も認められなかったが， 女児では全体として母乳群の数值が大きく，人工 群のそれが小さかった.

各年令層，男女とも，集団としてみた場合，人 工栄養児がとくに肥満であるという傾向は認めら れなかった。

4. 頭部計測値

（1）頭 囲（表 9)

表 9 に示した如く，4ケ月男子をのぞけば，3 才児以上の男児，ならびに女児の全年令について，

表 7 胸囲

(cm)

\begin{tabular}{|c|c|c|c|c|c|c|c|c|c|c|c|c|c|}
\hline \multirow[t]{2}{*}{ 性 } & \multirow{2}{*}{ 年 令 } & \multicolumn{4}{|c|}{ 母 乳 栄 養 群 } & \multicolumn{4}{|c|}{ 混 合 栄 養 群 } & \multicolumn{4}{|c|}{ 人工栄 養 群 } \\
\hline & & $\mathrm{n}$ & M & S.E. & S.D. & $\mathrm{n}$ & M & S. E. & S.D. & $\mathrm{n}$ & M & S.E. & S.D. \\
\hline \multirow{3}{*}{ 男 } & 4 ケ月児 & 121 & 43. 90 & 0.20 & 2.15 & 178 & 43. 81 & 0.14 & 1. 84 & 195 & 43.39 & 0.15 & 2.16 \\
\hline & 3 才児 & 44 & 52.00 & 0.26 & 1.91 & 58 & 52.09 & 0.24 & 1.86 & 162 & 52.37 & 0.17 & 2.12 \\
\hline & 5 才児 & 31 & 57.24 & 0.52 & 2. 88 & 37 & 56.09 & 0.48 & 2. 91 & 32 & 57.06 & 0.48 & 2.71 \\
\hline \multirow{2}{*}{ 児 } & 10 才児 & 106 & 64.43 & 0.28 & 2. 89 & 110 & 64.40 & 0.32 & 3. 35 & 104 & 64.50 & 0.56 & 5.74 \\
\hline & 12 才児 & 130 & 70.51 & 0.53 & 6.01 & 84 & 70.31 & 0.52 & 4. 76 & 72 & 70.25 & 0.56 & 4.73 \\
\hline \multirow{3}{*}{ 女 } & 4 ケ月児 & 115 & 42.70 & 0.21 & $2 .<0$ & 181 & 42.87 & 0.16 & 2. 20 & 156 & 42.37 & 0.16 & 1.96 \\
\hline & 3 才児 & 53 & 50.97 & 0.27 & 1.97 & 56 & 51.55 & 0.30 & 2.23 & 104 & 50.85 & 0.22 & 2.26 \\
\hline & 5 才児 & 33 & 54.95 & 0.50 & 2.87 & 46 & 55.20 & 0.51 & 3. 45 & 39 & 55.47 & 0.48 & 3.00 \\
\hline \multirow[t]{2}{*}{ 児 } & 10 才児 & 112 & 63.13 & 0.45 & 4. 75 & 79 & 63. 46 & 0.60 & 5.33 & 63 & 62.14 & 0.45 & 3.59 \\
\hline & 12 才览 & 148 & 72.12 & 0.46 & 5.55 & 82 & 71.63 & 0.60 & 5.40 & 51 & 70.49 & 0.77 & 5.49 \\
\hline
\end{tabular}


表 8 カウプ指数执よびローレル指数

\begin{tabular}{|c|c|c|c|c|c|c|c|c|c|c|c|c|c|c|}
\hline \multirow{2}{*}{$\begin{array}{l}\text { 性 } \\
\text { 別 }\end{array}$} & & \multirow{2}{*}{ 年令 } & \multicolumn{4}{|c|}{ 母 乳 栄 養 群 } & \multicolumn{4}{|c|}{ 混 合 栄 養 群 } & \multicolumn{4}{|c|}{ 人工栄 養 群 } \\
\hline & & & $\mathrm{n}$ & M & S. E. & S.D. & $\mathrm{n}$ & $\mathbf{M}$ & S. E. & S.D. & $\mathrm{n}$ & M & S. E. & S.D. \\
\hline \multirow{3}{*}{ 男 } & $\begin{array}{l}\text { 力 } \\
\text { ウ }\end{array}$ & 4 ケ月児 & 121 & 17.25 & 0.14 & 1.53 & 176 & 17.17 & 0.10 & 1.33 & 191 & 17.05 & 0.11 & 1.53 \\
\hline & プ & 3 才児 & 44 & 15.25 & 0.15 & 0.98 & 58 & 15. 41 & 0.12 & 0.92 & 154 & 15.37 & 0.10 & 1.22 \\
\hline & $\begin{array}{l}\text { 指 } \\
\text { 数 }\end{array}$ & 5 才児 & 31 & 14.67 & 0.20 & 1.14 & 37 & 14. 71 & 0.20 & 1.19 & 32 & 15.00 & 0.18 & 1.05 \\
\hline \multirow{2}{*}{ 児 } & ルㅁㅁㅁ & 10 才児 & 106 & 123.11 & 1.09 & 11.24 & 110 & 124.32 & 1.20 & 12.61 & 104 & & 1.77 & 18.02 \\
\hline & 数レ & 12 才児 & 130 & 122.23 & 1.27 & 14.48 & 84 & 121.19 & 1.25 & 11.50 & 72 & & 1.62 & 13. 73 \\
\hline \multirow{3}{*}{ 女 } & 力 & 4 ケ月児 & 115 & 17.04 & 0.16 & 1.75 & 181 & 16. 94 & 0.11 & 1. 52 & 155 & 16.76 & 0.12 & 1. 47 \\
\hline & プ & 3 才児 & 53 & 15. 24 & 0.14 & 1.05 & 56 & 15.30 & 0.20 & 1.47 & 104 & 14.94 & 0.11 & 1. 15 \\
\hline & $\begin{array}{l}\text { 指 } \\
\text { 数 }\end{array}$ & 5 才児 & 33 & & 0.17 & 0.98 & 46 & & 0.20 & 1. 34 & 39 & & 0.21 & \\
\hline \multirow[t]{2}{*}{ 児 } & ルロ & $10 才$ 览 & 112 & 124.33 & 1.19 & 12.55 & 79 & 124.15 & 1.54 & 13. 68 & 63 & 123.21 & 1.58 & 12.53 \\
\hline & 数レ & 12 才児 & 148 & 124.32 & 1.38 & 16.76 & 82 & 124.51 & 1.40 & 12.64 & 51 & 123.09 & 1.81 & 12.93 \\
\hline
\end{tabular}

表 9 頭囲

(cm)

\begin{tabular}{|c|c|c|c|c|c|c|c|c|c|c|c|c|c|}
\hline \multirow{2}{*}{$\begin{array}{l}\text { 性 } \\
\text { 別 }\end{array}$} & \multirow{2}{*}{ 年 令 } & \multicolumn{4}{|c|}{ 母乳 栄 養 群 } & \multicolumn{4}{|c|}{ 混 合 栄 養 群 } & \multicolumn{4}{|c|}{ 人工栄 養 群 } \\
\hline & & $\mathrm{n}$ & $\mathbf{M}$ & S. E. & S. D. & $\mathrm{n}$ & $\mathbf{M}$ & S. E. & S. D. & $\mathrm{n}$ & M & S. E. & S.D. \\
\hline \multirow{3}{*}{ 男 } & 4 ケ月児 & 121 & 42.11 & 0.10 & 1.05 & 178 & 42. I5 & 0.08 & 1.10 & 195 & 41.56 & 0.09 & 1.32 \\
\hline & 3 才児 & 44 & 50.65 & 0.21 & 1.37 & 59 & 50.30 & 0.19 & 1.49 & 162 & 50.68 & 0.10 & 1. 27 \\
\hline & 5 才児 & 33 & 5 I. 46 & 0.23 & 1.30 & 39 & 51.42 & 0.20 & 1.24 & 34 & 51.76 & 0.20 & 1. 15 \\
\hline \multirow{2}{*}{ 児 } & 10 才児 & 108 & 53. 45 & 0.13 & 1.35 & 112 & 53.50 & 0.11 & 1.21 & 104 & 53. 19 & 0.14 & 1.43 \\
\hline & 12 才児 & 131 & 54.20 & 0.14 & 1.57 & 86 & 54.31 & 0.14 & 1.29 & 74 & 54.43 & 0.19 & 1.67 \\
\hline \multirow{3}{*}{ 女 } & 4 ケ月児 & 114 & 41.00 & 0.10 & 1.09 & 176 & 41.17 & 0.08 & 1.07 & 150 & 41.14 & 0.15 & 1. 18 \\
\hline & 3 才児 & 53 & 49.52 & 0.15 & 1.12 & 56 & 49. 94 & 0.18 & 1.28 & 104 & 49. 41 & 0.13 & 1.28 \\
\hline & 5 才児 & 33 & 50.75 & 0.20 & 1.13 & 46 & 50.63 & 0.18 & 1. 25 & 44 & 50.42 & 0.19 & 1.27 \\
\hline \multirow{2}{*}{ 児 } & 10 才児 & 113 & 52.72 & 0.15 & 1.58 & 82 & 52.71 & 0.13 & 1.17 & 64 & 52.71 & 0.17 & 1.39 \\
\hline & 12 才児 & 149 & 54. 22 & 0.12 & 1. 42 & 83 & 54. 31 & 0.15 & 1.35 & 52 & 54.10 & 0.20 & 1. 44 \\
\hline
\end{tabular}

表 10 頭長

$(\mathrm{mm})$

\begin{tabular}{|c|c|c|c|c|c|c|c|c|c|c|c|c|c|}
\hline \multirow{2}{*}{$\begin{array}{l}\text { 性 } \\
\text { 別 }\end{array}$} & \multirow{2}{*}{ 年 令 } & \multicolumn{4}{|c|}{ 母 乳 栄 養 群 } & \multicolumn{4}{|c|}{ 混 合 栄 養 群 } & \multicolumn{4}{|c|}{ 人工栄 養 群 } \\
\hline & & $\mathrm{n}$ & $\mathbf{M}$ & S. E. & S. D. & $\mathbf{n}$ & $\mathbf{M}$ & S. E. & S. D. & $\mathrm{n}$ & $\mathbf{M}$ & S. E. & S. D. \\
\hline \multirow{3}{*}{ 男 } & 4 ケ月児 & 118 & 134.20 & 0.56 & 6.04 & 174 & 133. 48 & 0.59 & . & 195 & 132. 75 & 0.46 & 6. 49 \\
\hline & 3 才児 & 44 & 167.32 & 1.11 & 7.39 & 59 & 165.34 & 1.09 & 8. 34 & 162 & 166.01 & 0.50 & 6.38 \\
\hline & 5 才览 & 33 & 168.58 & 1.20 & 6.89 & 39 & 169.51 & 1.09 & 6.83 & 35 & 170. 31 & 1.03 & 6.09 \\
\hline \multirow{2}{*}{ 児 } & 10 才児 & 108 & 174.83 & 0.63 & 6.60 & 112 & 174.64 & 0.57 & 6.06 & 104 & 172.69 & 0.69 & 7.03 \\
\hline & 12 才児 & 131 & 177.20 & 0.58 & 6.62 & 86 & 176.93 & 0.65 & 6.06 & 74 & 176.68 & 0.72 & 6.18 \\
\hline \multirow{3}{*}{ 女 } & 4 ケ月児 & 114 & 132.63 & 0.55 & & 176 & 132.81 & 0.47 & 29 & 153 & 131.82 & 0.55 & 6.74 \\
\hline & 3 才览 & 53 & 164.25 & 0.73 & 5.29 & 56 & 163.50 & 0.85 & 6.35 & 104 & 161.96 & 0.65 & 6.67 \\
\hline & 5 才児 & 33 & 168.15 & 1.09 & 6.25 & 46 & 166.00 & 0.88 & 5. 97 & 44 & 165.00 & 0.85 & 5.66 \\
\hline \multirow{2}{*}{ 児 } & 10 才児 & 113 & 171.18 & 0.66 & 7.05 & 82 & 170.66 & 0.64 & 5. 79 & 64 & 170.16 & 0.67 & 5.40 \\
\hline & 12 才児 & 149 & 174.19 & 0.53 & 6.47 & 83 & 174.08 & 0.70 & 6.38 & 52 & 173.46 & 0.93 & 6. 72 \\
\hline
\end{tabular}


有意の差は認められなかったが, 女児については， 母乳群に比して, 人工群の平均值は若干小さい傾 向が認められた。

4 ケ月男児については，人工群の頭囲は 41.56 $\pm 0.09 \mathrm{~cm}$ で，母乳群の $42.11 \pm 0.10 \mathrm{~cm}$, および混 合群の $42.15 \pm 0.08 \mathrm{~cm}$ に比して極めて小さく, 危 険率 $0.01 \%$ 以下で有意の差が認められた。

（2）頭 長（表10）

表10に示したように，5才児を除き，各年令層， 男女とも, 母乳群に比して, 人工群の頭長が短か く, しかも, 混合群が母乳群, 人工群の中間にく るものが多かった．男児では，4 ケ月児の母乳群
の $134.20 \pm 0.56 \mathrm{~mm}$ と人工群の $132.75 \pm 0.46 \mathrm{~mm}$ ， 10才児の母乳群の $174.83 \pm 0.63 \mathrm{~mm}$ と人工群の $172.69 \pm 0.69 \mathrm{~mm}$, ならびに混合群の $174.64 \pm$ $0.57 \mathrm{~mm}$ と人工群との間で，また，女児では 3 才児 の母乳群の $164.25 \pm 0.73 \mathrm{~mm}$ と人工群のと 161.96 $\pm 0.65 \mathrm{~mm}$ の間で，また 5 才児の母乳群の 168.15 $\pm 1.09 \mathrm{~mm}$ と, 人工群の $165.00 \pm 0.85 \mathrm{~mm}$ との間 で，いづれも危険率 $5 \%$ 以下で有意の差が認めら れた。 母乳群と人工群との間の頭長の差は, 平均 值で $1 \sim 3 \mathrm{~mm}$ 程度であった.

（3）頭 幅（表11）

表11に示す如く，栄養摂取法による差の認めら

表 11 頭幅

( $\mathrm{mm})$

\begin{tabular}{|c|c|c|c|c|c|c|c|c|c|c|c|c|c|}
\hline \multirow{2}{*}{$\begin{array}{l}\text { 性 } \\
\text { 別 }\end{array}$} & \multirow{2}{*}{ 年 令 } & \multicolumn{4}{|c|}{ 母 乳 栄 養 群 } & \multicolumn{4}{|c|}{ 混 合 栄 養 群 } & \multicolumn{4}{|c|}{ 人工栄 養 群 } \\
\hline & & $\mathrm{n}$ & M & S. E. & S. D. & $\mathrm{n}$ & $\mathbf{M}$ & S. E. & S. D. & $\mathrm{n}$ & $\mathbf{M}$ & S. E. & S. D. \\
\hline \multirow{2}{*}{ 男 } & 4 ケ月児 & 118 & 126.46 & 0.49 & 5. 29 & 174 & 127.01 & 0.42 & 5.53 & 195 & 127.16 & 0.42 & 5.86 \\
\hline & 3 才児 & 44 & 146.09 & 1.08 & 7.17 & 59 & 145.20 & 0.80 & 6.18 & 162 & 147.89 & 0.52 & 6.68 \\
\hline \multirow{3}{*}{ 児 } & 5 才児 & 33 & 151.12 & 0.98 & 5.61 & 39 & 149. 97 & 1.04 & .50 & 35 & 152. 26 & 0.99 & 5.84 \\
\hline & 10 才児 & 108 & 154.93 & 0.54 & 5.58 & 112 & 155.54 & 0.51 & 5.41 & 104 & 155.63 & 0.59 & 5. 97 \\
\hline & 12 才児 & 131 & 155.48 & 0.49 & 5.63 & 86 & 155.93 & 0.64 & 5.96 & 74 & 157.49 & 0.74 & 6.38 \\
\hline \multirow{3}{*}{ 女 } & 4 ケ月児 & 114 & 121.98 & 0.57 & & 176 & 122.14 & 0.42 & 5.51 & 153 & 122.78 & 0.52 & 6.49 \\
\hline & 3 才児 & 53 & 140.02 & 0.81 & 5.90 & 56 & 141.86 & 0.90 & 6.74 & 104 & 141.54 & 0.63 & 6. 47 \\
\hline & 5 才児 & 33 & 145.12 & 0.84 & 4. 82 & 46 & 146.30 & 1.09 & 7. 42 & 44 & 147.27 & 0.79 & 5.22 \\
\hline \multirow[t]{2}{*}{ 児 } & 10 才児 & 113 & 148.58 & 0.51 & 5.43 & 82 & 149.76 & 0.57 & 5. 16 & 64 & 150.19 & 0.79 & 6.28 \\
\hline & 12 才跾 & 149 & 150.88 & 0.44 & 5. 34 & 83 & 152.18 & 0.60 & 5. 49 & 52 & 151.96 & 0.76 & 5. 47 \\
\hline
\end{tabular}

表 12 頭 長 幅 指 数

\begin{tabular}{|c|c|c|c|c|c|c|c|c|c|c|c|c|c|}
\hline \multirow{2}{*}{$\begin{array}{l}\text { 性 } \\
\text { 別 }\end{array}$} & \multirow{2}{*}{ 年 令 } & \multicolumn{4}{|c|}{ 母 乳 栄 養 群 } & \multicolumn{4}{|c|}{ 混 合 栄 養 群 } & \multicolumn{4}{|c|}{ 人工栄 養 群 } \\
\hline & & $\mathrm{n}$ & $\mathbf{M}$ & S. E. & S. D. & $\mathrm{n}$ & $\mathrm{M}$ & S. E. & S. D. & $\mathrm{n}$ & $\mathrm{M}$ & S. E. & S. D. \\
\hline \multirow{3}{*}{ 男 } & 4 ケ月児 & 118 & 94.32 & 0.61 & & 174 & 95.49 & 0.51 & 6.77 & 195 & 96.24 & 0.49 & 6.82 \\
\hline & 3 才児 & 44 & 87.41 & 0.87 & 5.79 & 59 & 88: 08 & 0.75 & 5.77 & 162 & 89.28 & 0.46 & 5.80 \\
\hline & 5 才児 & 33 & 89.61 & 0.79 & 4.55 & 39 & 88.54 & 0.87 & 5.4 & 35 & 89.69 & 0.87 & 5.1 \\
\hline \multirow[t]{2}{*}{ 児 } & 10 才児 & 108 & 88.74 & 0.46 & 4. 79 & 112 & 89. 16 & 0.44 & 4.63 & 104 & 90.31 & 0.49 & 5.04 \\
\hline & 12 才児 & 131 & 87.92 & 0.39 & 4.50 & 86 & 88.30 & 0.52 & 4.79 & 74 & 89.27 & 0.55 & 4.76 \\
\hline \multirow{3}{*}{ 女 } & 4 ケ月児 & 114 & 92.28 & 0.68 & & 176 & & 0.50 & 6.62 & 153 & 93.44 & 0.61 & 7.57 \\
\hline & 3 才児 & 53 & 85.38 & 0.70 & 5.11 & 56 & 86.75 & 0.72 & 5.39 & 104 & 87.60 & 0.51 & 5.25 \\
\hline & 5 才児 & 33 & 86.33 & 0.86 & 4.92 & 46 & 88.09 & 0.82 & 5.53 & 44 & 89.59 & 0.73 & 4.82 \\
\hline \multirow[t]{2}{*}{ 児 } & 10 才児 & 113 & 86.91 & 0.46 & 4.89 & 82 & 87.90 & 0.51 & 4.60 & 64 & 88.03 & 0.63 & 5.00 \\
\hline & 12 才跾 & 149 & 86.68 & 0.37 & 4.54 & 83 & 87.67 & 0.54 & 4. 94 & 52 & 87.81 & 0.67 & 4.84 \\
\hline
\end{tabular}


れるのは，男児では 3 才児の混合群の $145.20 \pm$ $0.80 \mathrm{~mm}$ と人工群の $147.89 \pm 0.52 \mathrm{~mm}$ の間で危険 率 $1 \%$ 以下の，また12才児の母乳群の $155.48 \pm 0.49$ $\mathrm{mm}$ と人工群の $157.49 \pm 0.74 \mathrm{~mm}$ との間に危険率 $5 \%$ 以下の有意の差が認められ，いづれも人工群 が大であったが，他の年令層和よび女児では，各 年令層とも有意の差は認められなかった。

しかし，男女とも各年令層を通じて，いづれも 母乳群より人工群が $1 \sim 2 \mathrm{~mm}$ 程度, 頭幅の平均 值が大であった。 混合群は 3 才児男女，5才男 児，12才女児をのぞき，母乳群と人工群との中間 の值を示した。

（4）頭長幅指数（表 12 ，図 1，2，3，4，5）

頭長ならびに頭幅の計測值から，頭幅 / 頭長 $\times$

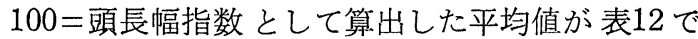
あり，それらの栄養摂取群別に示したものが図 1 〜 5 である. 各年令層, 男女とも，人工群は母乳 群に比して，指数で $1 \sim 3$ 程度の短頭となって抒 り，男児では，4ケ月児，10才児，12才児の母乳 群と人工群との間に危険率 $5 \%$ 以下で， また女児 でも人工群が 3 才児では危険率 $5 \%$ 以下で， 5 才 児では危険率 $1 \%$ 以下で，母乳群に比して頭長幅 指数が有意に大きかった。混合群は 5 才児をのぞ き，いづれも母乳群と，人工群との中間にあった が，両群との間に有意差はみられなかった。

男女の比較では各年令層とも，女児に比して男 児が短頭であって，その差は指数で $1 \sim 2$ 程度で あった。

表 13 知 能 偏 差 值

\begin{tabular}{|c|c|c|c|c|c|c|c|c|c|c|c|c|c|}
\hline 性 & 区 分 & \multicolumn{4}{|c|}{ 母 乳 栄 養 群 } & \multicolumn{4}{|c|}{ 混 合 栄 養 群 } & \multicolumn{4}{|c|}{ 人工栄 養 群 } \\
\hline 別 & & $\mathrm{n}$ & M & S.E. & S. D. & $\mathrm{n}$ & M & S. E. & S.D. & $\mathrm{n}$ & M & S. E. & S.D. \\
\hline 男 & 10 才児 & 102 & 50.29 & 0.94 & 9.49 & 103 & 50.56 & 0.89 & 9.06 & 100 & 49.65 & 0.90 & 9.01 \\
\hline 児 & 12 才児 & 125 & 49. 14 & 0.90 & 10.08 & 83 & 49. 25 & 0.90 & 8.23 & 72 & 50.56 & 1.14 & 9.70 \\
\hline 女 & 10 才児 & 113 & & 0.89 & 9.40 & 82 & 51.34 & 0.81 & 7. 34 & 63 & 49.33 & 1.03 & 8.18 \\
\hline 児 & 12 才児 & 147 & 48.85 & 0.71 & 8.64 & 80 & 49.81 & 0.91 & 8.18 & 50 & 50.40 & 1.18 & 8.31 \\
\hline
\end{tabular}

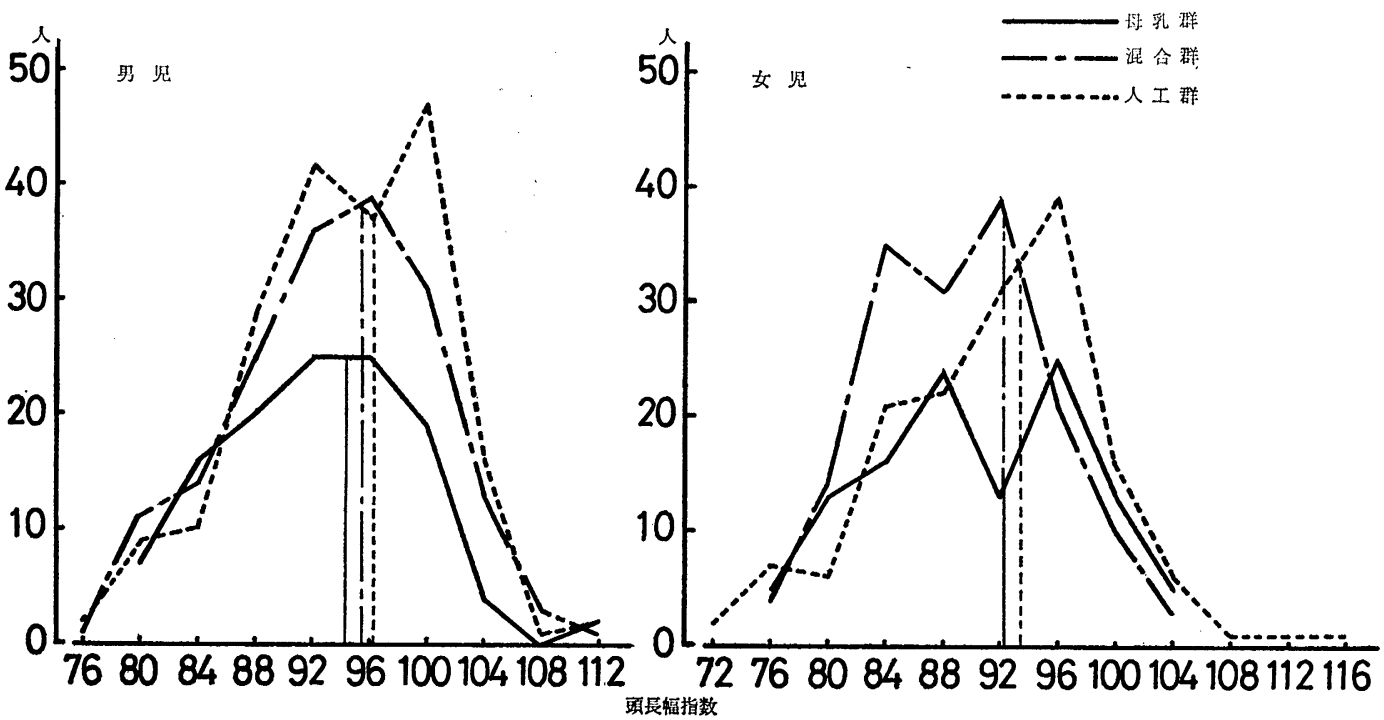

図 1 頭長幅指数の分布 (4 ケ月児) 

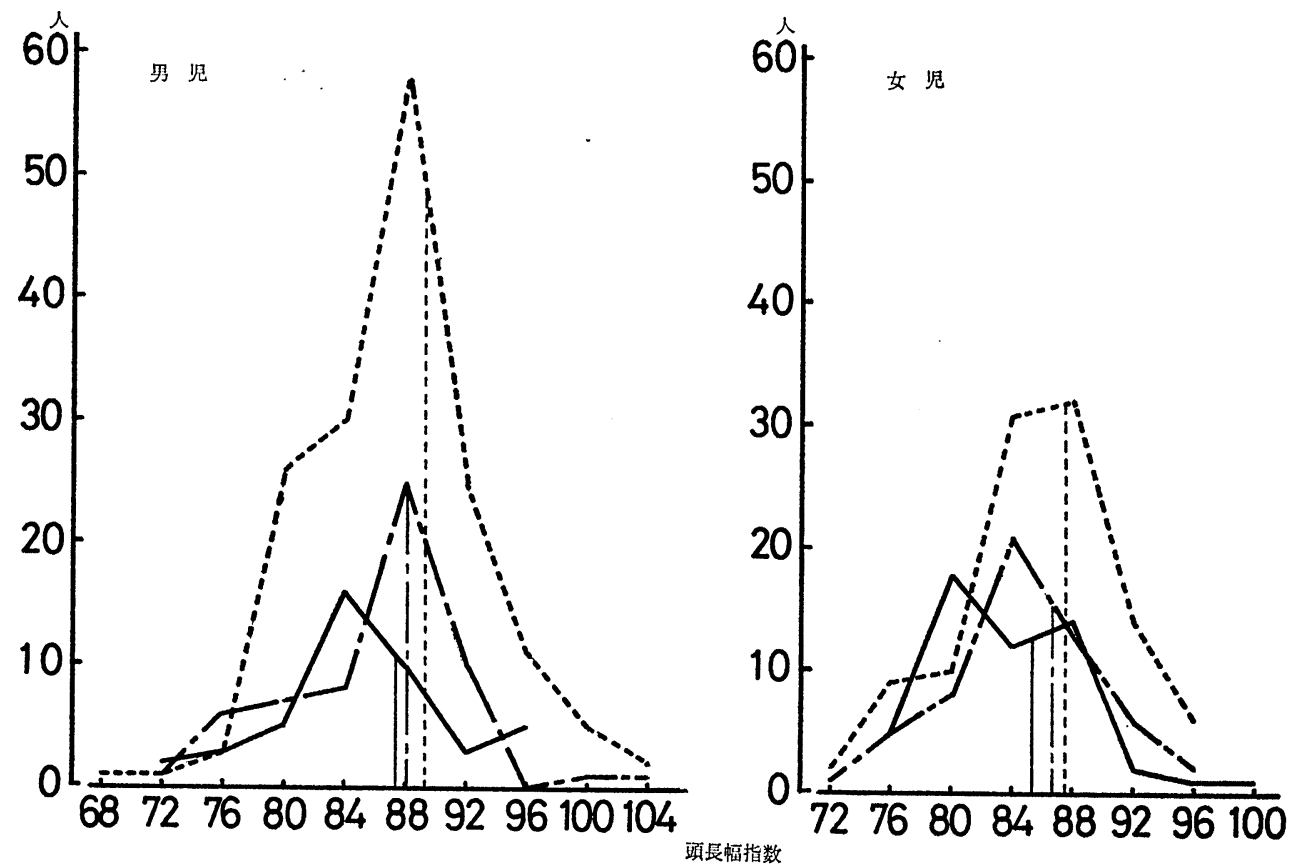

図 2 頭長幅指数の分布（3才児）
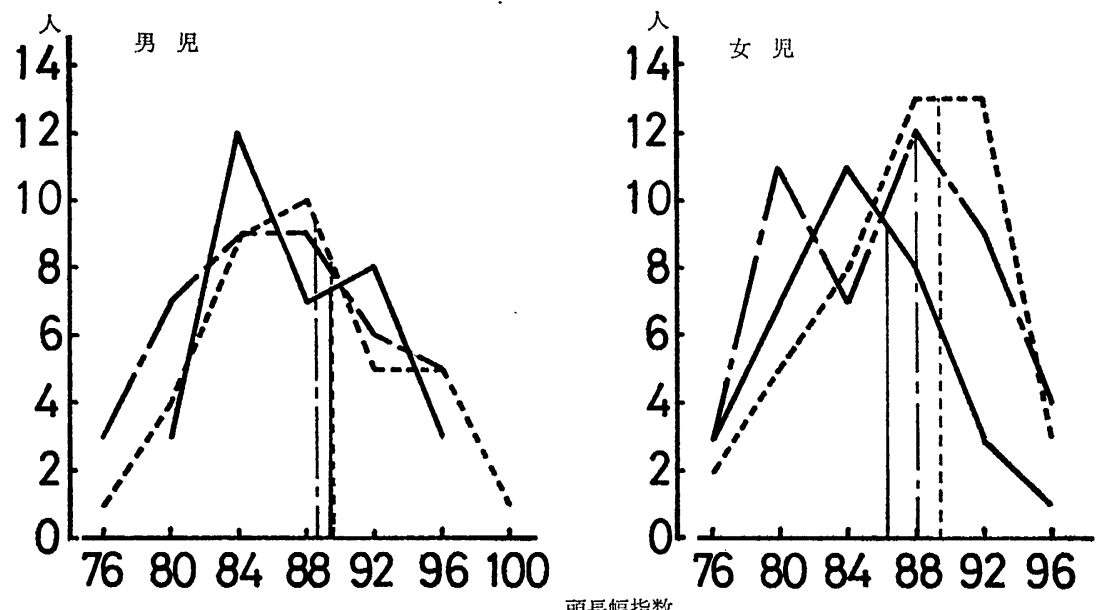

図 3 頭長幅指数の分布（ 5 才児） 

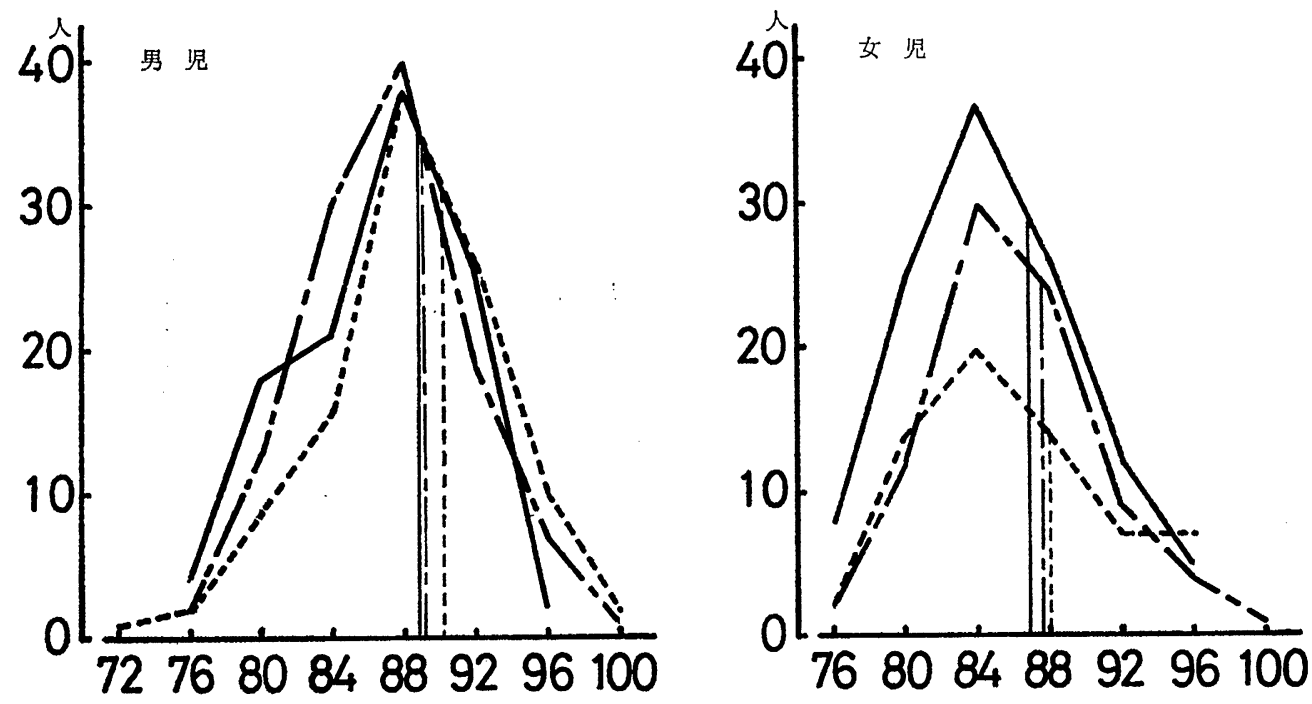

頭長幅指数

図 4 頭長幅指数の分布（10才児）
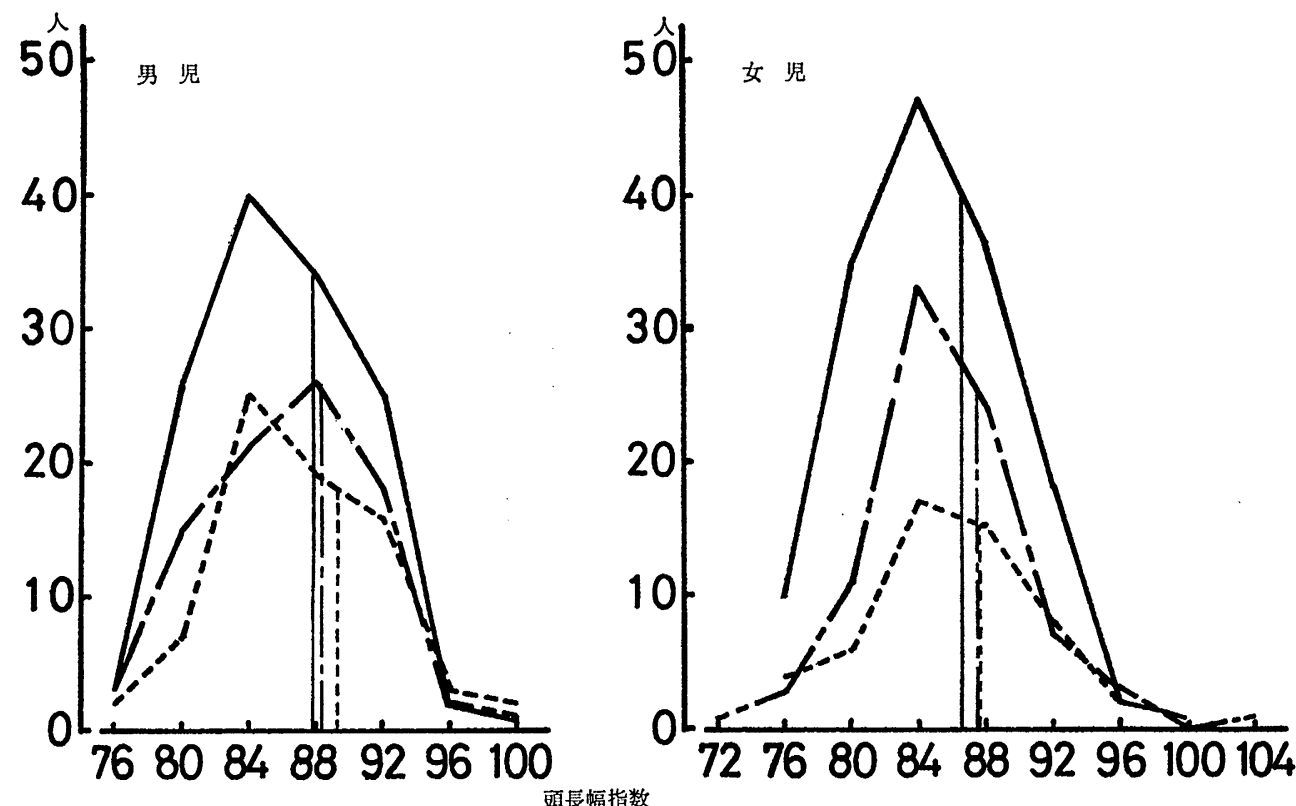

図 5 頭長幅指数の分布 (12才児) 
表 14 栄養摂取法群間の計測值の差の有意性

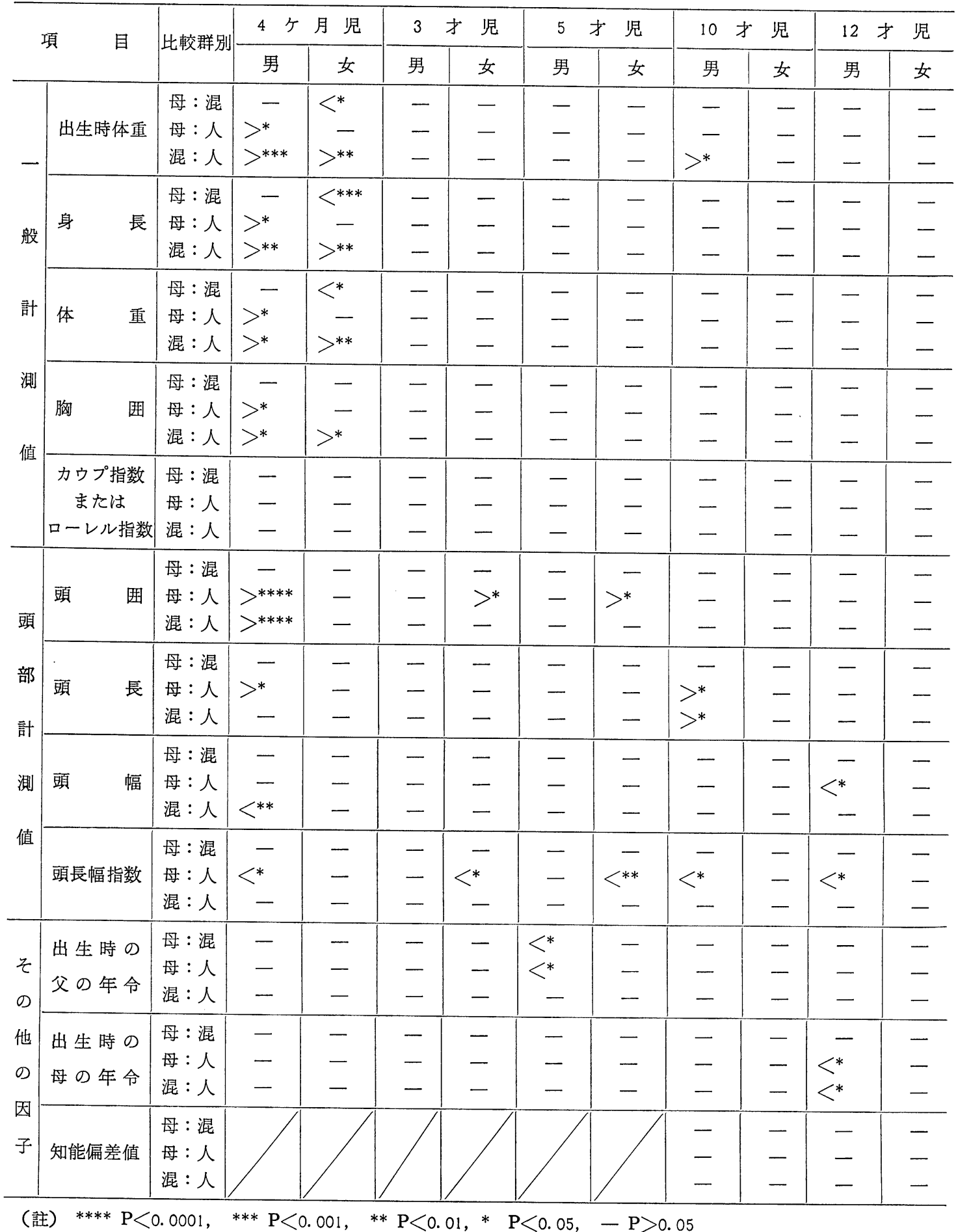




\section{5. 知能偏差值 (表13)}

教研式知能検查結果に基いて算出した10才児お よび 12 才児の知能偏差値の平均は，表13に示すご とく，両年令層の男女各群とも，ほぼ50附近にあ り，栄養掑取法群間に有意差はみられなかった。

\section{考察}

乳児期の栄養摂取法と身長，体重，胸囲の計測 值との関係について，斎藤6) は，その影響が乳児 期にはある程度認められるが，その後幼児期に至 って殆ど認められなかった，として扔り，著者の 今回の調査でも同様な成績が見られた（表14）.

4 ケ月児において頭囲は出生時に比して， $8 \mathrm{~cm}$ 前後の成長を示しているものであるが7，男児の 人工群では，母乳群，混合群のいづれとの間にも $\mathrm{p}<0.01$ で有意に小さい值を示したことは，発育 の最初の段階に拈いて，母乳の利用の有無が頭部 発達に不可欠であることを，強く示唆しているも のと考兄られる。

頭四については，その後の発育のなかで有意の 差は認められないが, 頭長, 頭幅, 頭長幅指数に おいて，男女とも母乳群と人工群との間に有意の 差が認められたことは，出生後 4 ケ月以内の栄㽰 掑取法が長期にわたって影響を与えているものと 考えられる.

母乳群と人工群との頭長幅指数の差は，5才男 児で 0.08 と例外的に小さく, 5 才女児では 3.26 と 極端に大きかったが，それ以外の年令層では，男
児で 1. 35〜1.92，女児では 1.12〜2.22であった. 斉藤 ${ }^{8}$ は, $1959 〜 61$ 年生まれの満 3 才児の頭長， 頭幅についても計測し，母乳，混合，人工群の間 に有意差なしとしているが，頭長幅指数について は触れていない，この計測值より頭長幅指数を算 出すると，男児の母乳群 $(n=28)$ で 88.5 , 人工 群 $(\mathrm{n}=20)$ では 89.0 であり，女児では母乳群 $(\mathrm{n}=22)$ の 85.9 に対し，人工群 $(\mathrm{n}=17)$ は 89.3 で，指数值の差は，男児では拉よそ0.5，女児で は 3.4 となり，いづれも人工群が母乳群に比して 短頭となる結果がでている。この資料は少数例を 取り扱ったものであるが，ここでも今回の著者の 成績と同様な結果がみられている.

鈴木 ${ }^{2)}$ は，近年の短頭化の速度を，10年間に頭 長幅指数で 1 程度としているが，母乳を人工栄養 に変えることによって，同一年代でありながら， 10年ないし20年程度，短頭化を促進していること になり，短頭化の主たる要因が栄養掑取の量的， 質的な変化にあることを示しているものといえよ 了.

このことは，宮下 ${ }^{4)}$ が，都市および農村出身者 の間で頭部形態を比較した結果，危険率 $1 \%$ 以下 で，都市出身者が短頭であり，また非農家出身者 が農家出身者に比して短頭であることを示し，さ らに村田 ${ }^{9)}$ が，わが国の中部以東の 住民の頭長幅 指数について検討した結果, 関東, 東海地方住民 が，北海道，東北地方住民に比して短頭であると したことも一致する成績であり，これらの差異を

表 154 ケ月母乳栄養児の頭部形態の比較（1969年生れと 1926〜 28年生れ）

\begin{tabular}{|c|c|c|c|c|c|c|c|}
\hline & \multicolumn{2}{|l|}{ 男 } & & \multicolumn{3}{|c|}{ 児 } \\
\hline & & \multirow{2}{*}{$\begin{array}{l}1969 \text { 年生 } \\
\mathrm{M} \pm \mathrm{S} . \mathrm{E} .\end{array}$} & 1926 28年生 & \multirow{2}{*}{ 差の検定 } & 1969 年生 & 1926～28年生 & \multirow{2}{*}{ 差の検定 } \\
\hline & & & $\mathrm{M} \pm \mathrm{S} . \mathrm{E}$. & & $\mathrm{M} \pm \mathrm{S} . \mathrm{E}$. & $\mathrm{M} \pm \mathrm{S} . \mathrm{E}$ & \\
\hline 頭 & 長 & $134.20 \pm 0.56$ & $132.3 \pm 0.82$ & - & $132.63 \pm 0.55$ & $128.9 \pm 1.30$ & $\mathrm{P}<0.01$ \\
\hline 頭 & 幅 & $126.46 \pm 0.49$ & $119.0 \pm 1.09$ & $\mathrm{P}<0.0001$ & $121.98 \pm 0.57$ & $117.8 \pm 1.13$ & $\mathrm{P}<0.01$ \\
\hline 頭 & 囲 & $421.1 \pm 0.10$ & $406.9 \pm 2.36$ & $\mathrm{P}<0.0001$ & $410.0 \pm 0.10$ & $397.0 \pm 2.65$ & $\mathrm{P}<0.0001$ \\
\hline \multicolumn{2}{|c|}{ 頭長 幅 指数 } & $94.32 \pm 0.61$ & $89.8 \pm 1.26$ & $\mathrm{P}<0.01$ & $92.28 \pm 0.67$ & $91.3 \pm 1.00$ & - \\
\hline
\end{tabular}

（註）1926〜28年生れとついては小林 ${ }^{11}$ とよる， 
生ずる原因として，一般に，都市部の住民が農村 部の住民に比し，また，関東，東海地方人が，北 海道東北地方人に比して，栄養撕取がすぐれてい るとされていることに一致するものである.

しかし，著者の成績で，4 ケ月児の人工群の身 長，体重，胸囲，頭囲が有意に小さかったことは， 短頭化を来す条件を備光た人工栄養が，体全体の 発育から見た場合，必ずしも栄養学的にすぐれた ものであることを示しているものとはいえず，む しろ同一年代の，乙かも，発育の初期に和ける極 端な短頭化は，この時期に拈ける人工栄養児の栄 養椇取のアンバランスが，もたらした結果である とい觉るかもしれない.

頭部形態の性差に関しては Miklaschevskaya ${ }^{10)}$ と同様，全体として頭囲，頭長，頭幅とも男児が 大であり，頭長幅指数值も男児が大で，女児に比 し短頭であることを示している．このことは，各 栄養㠌取法ごとに比較しても，各計測做とも同様 なことがいえる。

小林 ${ }^{11)}$ は，1926〜28年に京都附近で生まれた母 乳栄養児について，頭部形態の測定を行ない，頭 長，頭幅，頭囲ともに女児が，男児に比して小さ く，今回の著者の成績とも一致しているが，頭長 幅指数值では，今回の調査結果とは逆に，女児が 指数值で 1.5 程度短頭であった (表15). 4 ケ月男 児での頭長幅指数は，地域差をのぞいて考えれば， 約 40 年の時間的経過の間に，4.5 程度の增加とな り，短頭化が促進されているといえる．前述のよ うに鈴木 ${ }^{2)}$ は，短頭化の速度が 10 年間で指数で 1 程度としているが，これと一致を示している。 し かし女児では， 40 年間に指数值で 1 の短頭化がみ られたにすぎなかった。

これに対し，身体の一般計測值では，备栄養群 間に特定の傾向を示さなかったことは，5才頃ま でに90\%が完成されるといわれる．Scammonの いわゆる神経型器官と，20才頃までに完成される といわれる一般型器官に対する乳児栄養の影留の ちがいを示したものと考えられる。

これらの成績に 影響を与えると思われる因子の 1 つに出生時の両親の年令があるが, 出生時の父
の年令については，12才児の父から4ケ月児の父 にさかって，若干の若年化傾向は認められるが， 母親の年令には変化がみられなかったことは，女 子の結婚年令，あるいは出産年令に影響を与学る よ5な，社会的経済的な要因があったものと考兄 られるが，その頭部形態に対する関係は不明であ る.

出生順位は，対息者の大部分が第 1 子もしくは 第 2 子であり，第 3 子以下は極めて少数で，第 1 子, 第 2 子間に頭部形態の差異は認められなかっ た.

頭部形態が 乳児期の栄養摂取法の差異によって 影響され，乙かも長期にわたって，执そらくは生 涯にわたって継続すると考兄られることから，10 才児，12才児について実施した教研式知能検查の 結果から知能偏差值を求め, 各栄養摄取群毎に比 較したが，10才児，12才児とも，頭長幅指数の傾 向は同一であるにかかわらず，知能偏差值の傾向 には同一のパターンは見られず，かつ，いづれも 有意の差は認められなかった。しかし，乳児期の 栄養摂取法が頭部形態に影陮を及ぼし，短頭化を 促していることと，明治時代以後の日本人頭型に 急激な短頭化がみられることを関連ずけると，遺 伝的要因のみならず，環境的要因によって大きく 左右される頭部形態の変化が，さらに，ヒトの知 的, 情緒的発育になんらかの影響を与えているか どうか学注意深く見守ることが必要であろう。

乳児の栄養が，本来は母乳であったことはいう までもないが，近年の人工栄養法の発達に伴な い，母乳を全く用いない育児法が広く普及し，今 回の調査に和いても，3才児群にあっては $50 \%$ を こえる人工栄養児があったことは，母乳が得られ なかった場合の非常用食糧としての人工栄養のあ り方を全く変えてしまったものということもでき よ5. 母乳と人工栄養についての比較は, 従来か ら多くの研究があり，母乳栄養児と人工栄養児の 身体的，精神的発達に関するもの，母乳之人工栄 養との成分の比較を行なったものが，それらの中 心となっている. 斎藤6) は, 乳児期の栄養掑取法 毎に，生後数年間にわたる縦断的研究を行ない， 
その発衣について，乳児期にはある程度の差は認 められるが，幼児期になるとその影響は殆んどな くなるとしている. しかし，少数例による調査で あり，これによって人工栄養とのものを是とする ことはできない。

母乳の成分について，中山 ${ }^{12)}$ はその分析例を紹 介し，また，東郷(3) は母乳の成分のちがいによる 発育への影響について，蛋白濃度が低い場合には 十分な発育が妨げられるとしている. Aitken ら ${ }^{14)}$ は，母乳と人工栄養について，その化学成分とと もに, 体重の増加, 骨発育, 死亡率等に対する影 響について從来の研究を総括して和り，また，今 村ら ${ }^{15)}$ は人乳々人工栄養乳について，それぞれの ミネラル含量についての比較を行ならとともに, 人工栄養品のミネラル 10 種類を年次別に比較する ことにより，これらのミネラル含量が年代の経過 に伴って変化してきていることを示している.

著者の今回の調査対象者は, 1957〜 58 年生まれ のものから，1969年生まれのものまで，12年間に わたっており，その間に各乳業メーカーとも， 3 〜 種類の異なったタイプの育児用粉乳を発売し ている.すなわち，育児用粉乳についての前記今 村らの分析值, ならびに各メーカーの成分表によ ると, 1953〜 58年, 1959〜 61年, 1962～65年, 1966年からとの 4 期を通じて, 灰分， K, Na, Ca， $\mathrm{Mg}, \mathrm{P}, \mathrm{Cl}, \mathrm{Zn}$ では急激な減少, $\mathrm{Cu}, \mathrm{Mo}$ の若干 の減少が見られるとともに， $\mathrm{Fe}$ が極端に多く，乙 かも 4 期を通じて殆んど変っていないことが知ら れる.このようなミネラルの変動に対し, 蛋白質, 脂肪, 炭水化物等も, メーカーによってかなりの らがいがあるものの，4期を通じて変ってきてお り，殊に，脂質ならびに炭水化物については，メ 一カー毎にかなりのちがいがみうけられる。従が って調查した各年令層の対档者が，同一の人工栄 養を撕取しているのでないのにかかわらず，特に 頭部形態において，活とんぞ同じ傾向の変化を示 し，母乳栄養児に比して人工栄養児が短頭であっ たことは，その後の発育に対して，発育初期の栄 養摂取法が極めて重要な影響を与光，さらに，生 涯を通じて継続していくことを示しているもので
あろう。

母乳成分が泌乳時期に応じて変化していくこと は, 乳児の発育発達の段階に対して，母体がなん らかの適応を示しているものとも考兄られるが， 人工栄養の場合には，出生後最初の段階から離乳 期に至るまで，同一成分比のものを与えられるこ とになり, 発育発達の段階に応じたものとはなら ず，守田 ${ }^{16)}$ ，浜本叔よび守田 ${ }^{17)}$ のいうように「乳 児の人工乳に対する適応能力」に期待したもので しかないことは充分に考えられる.人工栄養に扤 いて認められた短頭化傾向は，このような乳児の 人工乳に対する適応能力のひとつの表現型とも考 えられよ5。あたこのことから，わが国ならびに 世界各国に沶いて認められている短頭化の原因 が，農業技術の進歩に伴なら，食糧の量的和よび 質的な向上によるものであろうことは，特にわが 国に找ける明治以後の食生活の変化と，急激な短 頭化現象とがつよく平行していることからも充分 考えられることである.

\section{要約}

頭部形態に拈ける短頭化現象と栄養摄取との関 連を究明するために，仙台市南保健所管内に居住 する 4 ケ月児， 3 才児， 5 才児，10才児，12才児 の男女合計 2796 名について, 乳児期の栄養摂取法 により, 母乳栄養, 混合栄養, 人工栄養の 3 群に 分け，頭部形態の発育を中心に横断的調査を行な い，短頭化の原因究明の一助となる知見を得た.

1. 身長，体重，胸囲等の一般的計測值は，4 ケ月児の人工群がやや小さかった湾かは，各 年令層, 男女とも差は認められなかった.

2. 頭部形態計測の結果, 人工群では男女, 各 年令層ともに，母乳群に比して頭長が短かく 頭幅は広く短頭であり，4 ケ月，10才，12才 の男児，ならびに 3 才，5才の女児では，両 群間に有意の差を認めた。混合群は，前記両 群の中間に位置した.

3. 頭囲は 4 ケ月男児で，人工群が有意に小さ かったほか，有意の差は認められなかった。 また女児でも人工群は，若干小さい傾向が認 
められたが有意な差ではなかった。

その発育について，乳児期にはある程度の差は認

4. 10才児，12才児の知能偏差值には，乳児栄 養との関係は認められなかった。

5. 出生時の父母の年令々乳児栄旋の選択との 関連は認められなかった。

6. 以上のことから, 出生淔後, 極めて短い期 間の栄養摂取法が頭部形態の発䘚に影響を与 え，それが生涯にわたって継続するであろう ことが示唆され，歴史的な短頭化現象も，各 時代の栄養掑取状態の反映であると推測され た。

稿を終るに当り，御指導ならびに御校閲を賜わ った，東北大学教授高橋英治先生，秋田大学教授 加美山茂利先生，ならびに本調查に御援助を賜わ った。 仙台市南保健所長阿部睦男先生に深甚の謝 意を表します。

\section{文献}

1）鈴木 尚：石器時代より昭和時代飞至る日本人頭 型の時間的推移飞ついて, 解剖誌, 28,'23〜24, (1953)

2）跉木 尚：日本人の骨，82１07，岩波書店，(1963）

3）附田鎮厦：日本人頭型の地域差飞ついて, 民族衛 生, 21，133〜145（1955）

4）宮下智也：顔面頭蓋ことに外舅形態の構成に関す る疫学的研究. 第 1 報, 生育環境を異にした青年期 群飞打ける比較，民族衛生，34，168～194（1968）

5）宮下智也：同 第 2 報, 農 - 漁村住民打ける比 較，民族衛生，34，195２13（1968）

6）斎藤マサ：乳幼児の身体発育並びて精神発達飞関
する逐年的研究，第 8 報，栄養方法別飞見た満 5 年 児の発育状況と生後 5 年間の発育の経過飞ついて （その 2)，鹿大教研紀，18，105１19（1966）

7）厚生省児童家庭局編：昭和 45 年乳幼児身体発育調 查結果報告書, 17, 大藏省印刷局（1971）

8）斉藤マサ：乳幼児の身体発育並びに精神発達に関 する逐年的研究，第 4 報，栄等方法別飞見た満 3 年 児の発育状況について，鹿大教研紀，16，26～33 (1964)

9）村田四郎：本邦中部以東日本人の頭長幅指数飞関 する筞与, 十全会誌，40，1349～1370（1935）

10) Miklascherskaya, N. N. : Sex differences in growth of the head and face in children and adolescents, Human Biol., 41(2), 250 262 (1969)

11) 小林 貞: 本邦健康哺乳児身体ノ部分的発育二就 テ, 第 1 編, 頭部及ビ顔面計測, 乳児学雑誌, 7 (1), $5 \sim 110$ (1930)

12) 中山健太郎：新らしい乳児栄庝の実際，(6 ed.), 145, 医学書院 (1964)

13）東郷正美：母乳成分と乳児の発育の関連に関する 研究, 日本公衛誌，13(14)，961～966（1966）

14) Aitken, F. C. and F. E. Hytten.: Infant feeding, comparison of breast and artificial feeding, Nutrition Abstracts and Reviews, 30 (2), $341 \sim 371$ (1960)

15）今村経明, 内藤 博, 青木孝良: 人乳々热児用調 整紛乳のミネラル，栄餎と食糧，22(6)，361〜366 (1969)

16）守田哲郎：特殊調整粉乳，臨床栄養， $40(2) ， 134$, (1972)

17）浜本英次, 守田哲朗: 乳幼児栄養の变遷々今後の 展開 (対談)，臨床栄養，40(1)，70～81（1972） 